\title{
EFFECTS OF DISINFECTANTS AND ANTI-BROWNING AGENTS ON THE SHELF-LIFE OF CAULIFLOWER FLORETS
}

\author{
A Thesis \\ presented to \\ the Faculty of California Polytechnic State University, \\ San Luis Obispo
}

\begin{abstract}
In Partial Fulfillment
of the Requirements for the Degree

Master of Science in Agriculture, with Specialization in Crop Science
\end{abstract}

by

Joel David Harris

August 2011 
(C) 2011

Joel David Harris

ALL RIGHTS RESERVED 
TITLE:

AUTHOR:

DATE SUBMITTED:

COMMITTEE CHAIR:

COMMITTEE MEMBER: Brian C. Hampson, PhD

COMMITTEE MEMBER: Jeffrey C. Wong, PhD CAULIFLOWER FLORETS

Joel David Harris

August 2011

J. Wyatt Brown, PhD

EFFECTS OF DISINFECTANTS AND ANTIBROWNING AGENTS ON THE SHELF-LIFE OF 


\section{ABSTRACT \\ EFFECTS OF DISINFECTANTS AND ANTI-BROWNING AGENTS ON THE SHELF-LIFE OF CAULIFLOWER FLORETS}

Joel David Harris

Currently, when cauliflower florets are packed in a MA package, they can last 8 to 10 days at $7.2^{\circ} \mathrm{C}$. The goal of this research was to develop a prepackaging methodology that could extend shelf-life of cauliflower florets to at least 14 days at $7.2^{\circ} \mathrm{C}$. Various methodologies were used to treat the cauliflower florets, utilizing six GRAS (generally recognized as safe) chemicals and included various combinations, concentrations, and contact times. Chemicals included gaseous ozone, calcium chloride, citric acid, ascorbic acid, chlorine dioxide and sodium hypochlorite. The combination of 250 ppm ascorbic acid and 500 ppm citric acid pre-wash (30 seconds) and a 100 ppm hypochlorite wash (30 seconds, with $\mathrm{pH}$ adjusted to 6.5) proved to significantly reduce overall floret browning that develops in storage but did not reduce levels enough for it to be considered a commercially viable method. Further studies should explore the synergistic effects of combining enzymatic browning inhibitor treatments with microbial browning inhibitor treatments. 


\section{ACKNOWLEDGMENTS}

First and foremost, I would like to thank Dr. Wyatt Brown for all of your time and patience. This thesis would not have been possible without your guidance and support throughout my graduate and undergraduate studies. You introduced me to the field of postharvest technology and for that I am grateful.

I am indebted to Gold Coast Packing for their commitment to my studies by offering produce, financial support, and guidance in what the industry is trying to achieve with cauliflower. You provided me with an experience in how take my education and apply it to a commercial application.

Dr. Hampson, I appreciate all that you taught me, but I really want to thank you for your lessons in food microbiology. It has become a crucial aspect of my current profession, and without the principles that you taught me I would be lost.

Dr. Wong, I want to thank you for providing me support for my graduate studies, but also for being flexible and having a positive attitude with all of the delays I encountered in completing my thesis.

I owe my deepest gratitude to my family. You have supported me throughout my education with encouragement and guidance. Mom and Dad, you have shown me the true meaning of having a good work ethic and for that I am grateful. Maryelyse, I

treasure your confidence in my abilities and your unwavering support and encouragement in helping me complete my Master’s degree. Thank you all.

Joel Harris 


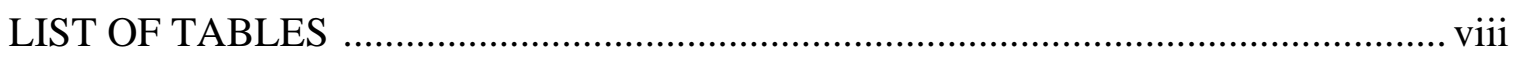

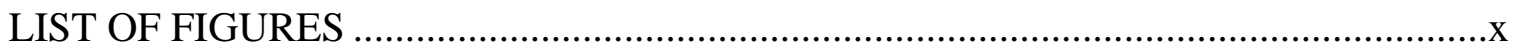

\section{CHAPTER}

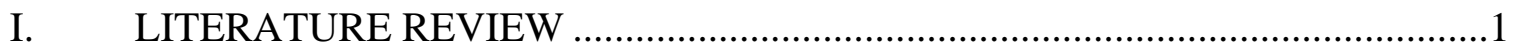

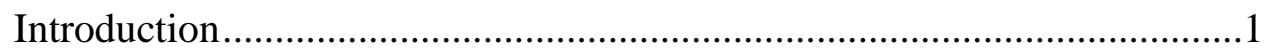

Storage Conditions ...................................................................................

Atmospheric Modification ............................................................................

Cauliflower and MAP:CA …………………………….......................6

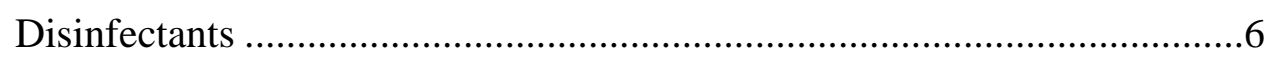

Antibrowning Agents...........................................................................

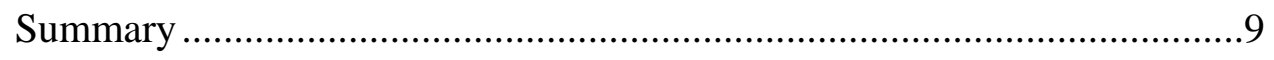

II. MATERIALS AND METHODS ..................................................................11

Microbiological Testing.........................................................................11

Ozone and Cauliflower Browning ............................................................11

Calcium Chloride and Cauliflower Browning ............................................16

Antibrowning Agents with Hypochlorite....................................................17

Antibrowning Agents, then Hypochlorite....................................................19

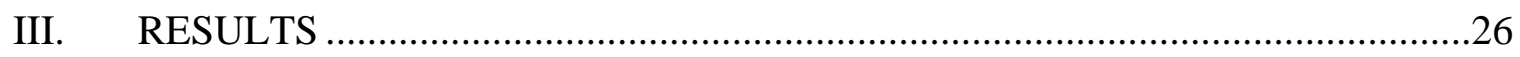

Microbiological Testing ...........................................................................26

Ozone and Cauliflower Browning .........................................................26

Calcium Chloride and Cauliflower Browning ............................................2 
Antibrowning Agents with Hypochlorite...........................................28

Antibrowning Agents, then Hypochlorite.................................................32

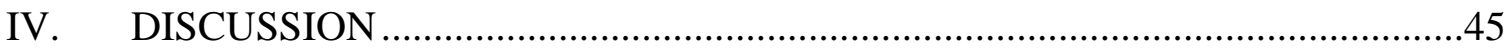

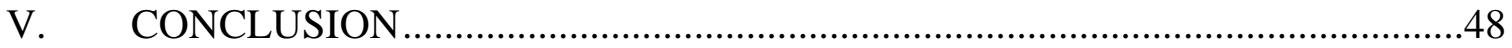

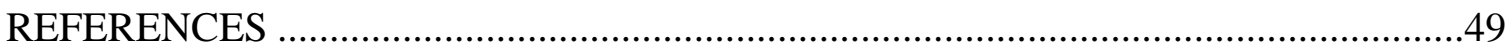




\section{LIST OF TABLES}

Table

Page

1. Potential beneficial and harmful effects that atmospheric modification can have on produce stored in controlled atmosphere (CA) or modified atmosphere (MA) environments

2. Calcium chloride, ascorbic acid, citric acid, hypochlorite combinations and concentrations used to treat cauliflower florets.

3. Ascorbic and citric acid combinations, and hypochlorite concentrations, used in a two-step cauliflower wash sequence.

4. Hypochlorite concentration and ascorbate:citric acid combinations used in a two-step cauliflower wash sequence.

5. Chlorine dioxide, hypochlorite and ascorbate:citric acid combinations used in a two-step cauliflower wash sequence.

6. Rankings of overall quality, as determined by browning, for cauliflower florets treated with $\mathrm{CaCl}_{2}$ where $1=$ most effective and $3=$ least effective

7. Results of overall quality for cauliflower florets treated with $\mathrm{CaCl}_{2}$. Each package was scored for percentage of florets that were still edible at the end of the study.

8. Quality of cauliflower florets treated with various $\mathrm{CaCl}_{2}$ :ascorbic acid:citric acid:sodium hypochlorite combinations. Florets were evaluated after fourteen days storage.

9. Rankings of overall quality for cauliflower florets stored for nine days. Values are for the first replicate of each treatment, only.

10. Curd and stem browning scores for cauliflower florets stored for 15 days.

Results are for replicates two and three of each treatment.

11. Overall score for cauliflower florets stored for 15 days. Results were for replicates two and three of each treatment.

12. Curd and stem browning scores of cauliflower florets stored for 22 days. Results are for replicates two and three of each treatment.

13. Overall discoloration scores for cauliflower florets stored for 22 days based on replicates four, five and six of each treatment. 
14. Curd and stem browning of cauliflower florets stored for 14 days.

Results were for all replicates of each treatment.

15. Overall quality of cauliflower florets stored for 14 days. Results were for all replicates of each treatment and were based on both curd and stem browning scores.

16. Rankings of curd quality for cauliflower florets stored for 14 days. Results were for all replicates of each treatment.

17. Rankings of overall quality for cauliflower florets stored for 14 days. Results were for all replicates of each treatment.

18. Quality rankings for cauliflower florets stored for 14 days. Results were for all replicates of each treatment.

19. Overall quality of cauliflower florets stored for 14 days. Results were for all replicates of each treatment. 


\section{LIST OF FIGURES}

Figure Page

1. Plastic modified-atmosphere shipping boxes (SLX International, San Luis Obispo, CA) used to store cauliflower during ozone treatment. Inlets and outlets for the ozonated air are visible.

2. Del Industries (San Luis Obispo, Ca) ozone generator model ZO-156T produces $150 \mathrm{mg} \mathrm{O}_{3}$ /hour.

3. Microperforated bag packed with $1.36 \mathrm{~kg}$ of cauliflower florets. Bags and cauliflower were supplied by Gold Coast Packing (Santa Maria, Ca).

4. Image of cauliflower florets that have developed stem (left) and curd (right)

browning. 


\section{Literature Review}

\section{Introduction}

Cauliflower (Brassica oleracea L., Group Botrytis) is a cool-season vegetable crop and member of Brassicaceae (the Mustard family). Cauliflower, a cole crop, is closely related to cabbage (Brassica oleracea, Group Capitata), broccoli (Brassica oleracea, Group Italica), kale (Brassica oleracea, Group Acephala), and Brussels sprouts (Brassica oleracea, Group Gemmifera) (Brown, 2003).

Like many of its relatives, cauliflower provides many nutritional benefits to consumers. One-hundred grams provides $1.98 \mathrm{~g}$ of protein, $2.5 \mathrm{~g}$ of fiber, 22mg of calcium, and 46.4mg of vitamin C (National Agricultural Library, 2011).

Consumers generally have the choice of purchasing cauliflower either whole or as florets. A floret is defined as a tightly-branched cluster of flower primordial [Floret, 2011], and the head is formed of a number of florets. Cauliflower florets are typically packed in a plastic (micro-perforated) bag before distribution. Whole heads of cauliflower are generally wrapped with a film to prevent moisture loss before distribution.

\section{Storage Conditions}

Cauliflower must be stored properly to maintain its quality. Heads and florets should be stored at $0^{\circ} \mathrm{C}$ and 95-98\% relative humidity (RH) (Cantwell and Suslow, 2009; Hardenburg et al., 1993). At $0^{\circ} \mathrm{C}$, the respiration rate of cauliflower florets slows down to $\sim 8 \mathrm{ml} \mathrm{CO}_{2} / \mathrm{kg} \bullet \mathrm{hr}$ compared to $\sim 42 \mathrm{ml} \mathrm{CO}_{2} / \mathrm{kg} \bullet \mathrm{hr}$ at $22^{\circ} \mathrm{C}$ (Cantwell and Suslow, 
2009). If cauliflower is stored below 95\% RH, the tissues dry out. If stored above $98 \%$ $\mathrm{RH}$, microbial activity on the cauliflower increases and spoilage occurs more rapidly (Cantwell and Suslow, 2009; Hardenburg et al., 1993).

Many problems can develop during storage that cause cauliflower heads or florets to become unmarketable. These include curd browning and/or bruising, leaf yellowing, anaerobiosis, and freezing injury.

Curd browning occurs enzymatically through the action of polyphenol oxidase. Polyphenol oxidase is enzyme prevalent in many plant tissues which, in the presence of oxygen and a copper cofactor, converts phenols into quinones which rapidly polymerize into colored pigments such as melanin (Brown, 2003). In addition, browning can occur when a fungal or bacterial pathogen infects the plant tissue. Erwinia and Pseudomonas are common bacterial pathogens that can cause browning of the curd, while Alternaria alternata and Botrytis cinerea are fungal pathogens that are also known to cause browning of cauliflower florets (Cantwell and Suslow, 2009).

Due to cauliflowers susceptibility to bruising, heads of cauliflower are trimmed so that the wrapper leaves remain to provide protection from bruising. Bruised cauliflower appears as watery, brown or dark brown curd discoloration (Canadian Food Inspection Agency, 2011). The wrapper leaves may discolor and turn yellow. When this happens, it indicates a decrease in overall quality.

Cauliflower will develop off-odors when the storage atmosphere drops to $<0.5 \%$, due to anaerobiosis (Forney and Jordan, 1999). The odors are due to the formation of mercaptans. 
Like bruising, freezing injury appears as a watery or brownish discoloration (Canadian Food Inspection Agency, 2011). Freezing occurs when cauliflower is stored below $0.78^{\circ} \mathrm{C}$ (Mitchell et al., 1972).

Cauliflower florets have been stored, under optimal conditions in a controlled atmosphere (CA) for up to 33 days, but commercial packers of cauliflower florets seek a 16-day shelf-life (Ratti et al., 1998). Commercial packers are unable to achieve a 33-day shelf-life due to the large temperature fluctuations throughout processing, storage, and transportation coupled with the non-precise, modified atmosphere (MA) packaging used with the heads and florets.

\section{Atmospheric Modification}

The terms controlled and modified atmospheres refer to gas mixtures, surrounding commodities, that differ in composition from that of normal air (78.08\% nitrogen, 20.95\% oxygen, and $0.03 \%$ carbon dioxide at one atmosphere pressure) (Kader and Saltveit, 2003). In CA storage, the atmosphere within a room or container is continually monitored and adjusted to maintain pre-set levels of oxygen (usually decreased with respect to normal levels) and carbon dioxide (usually increased with respect to normal levels) around a commodity (Kader and Saltveit, 2003). Originally, this atmospheric modification was called "gas storage," after World War I the name was changed (Kader and Saltveit, 2003). By the 1930's, CA storage was being used commercially with apples in the U.S. and England (Kader and Saltveit, 2003) due to its many beneficial effects (Table 1). 
Table 1. Potential beneficial and harmful effects that atmospheric modification can have on produce stored in controlled atmosphere (CA) or modified atmosphere (MA) environments (from Kader and Saltveit, 2003).

\section{Potential Beneficial Effects}

1) Retardation of senescence and associated biochemical and physiological changes.

2) Reduction of the commodity's sensitivity to ethylene action at $\mathrm{O}_{2}$ levels below about $8 \%$ and/or $\mathrm{CO}_{2}$ levels above $1 \%$.

3) Alleviation of certain physiological disorders, such as chilling injury of various commodities and russet spotting in lettuce.

4) Controlled and modified atmospheres can have direct or indirect effects on postharvest pathogens and consequently decay incidence and severity.

5) Atmospheres of low $\mathrm{O}_{2}$ ( $0.5 \%$ or lower) and/or elevated $\mathrm{CO}_{2}(40 \%$ or higher) can be useful tools for insect control in some commodities.

\section{Potential Harmful Effects}

1) Initiation and/or aggravation of certain physiological disorders such as blackheart in potatoes (Solanum tuberosum L.) and brown stain on lettuce.

2) Irregular ripening of fruits such as melons (Cucumis melo L.) and tomato (Lycopersicon esculentum Mill.) can result from $\mathrm{O}_{2}$ levels below $2 \%$ or $\mathrm{CO}_{2}$ levels above $5 \%$.

3) Development of "off” flavors and odors at $<0.5 \% \mathrm{O}_{2}$ and/or $>20 \% \mathrm{CO}_{2}$ as a result of fermentative metabolism.

4) Increased susceptibility to decay when the commodity is physiologically injured by excessively low $\mathrm{O}_{2}$ or high $\mathrm{CO}_{2}$ concentrations.

5) Stimulation of sprouting and retardation of periderm development in some root and tuber vegetables such as potatoes. 
In MA packaging, the atmosphere surrounding the commodity is adjusted and/or maintained passively via the interaction of product respiration with the $\mathrm{O}_{2}: \mathrm{CO}_{2}$ permeability of the packaging material (Brown, 2003). Produce with a high respiration rate thus requires a packaging material with a high permeability to $\mathrm{O}_{2}$ and $\mathrm{CO}_{2}$ if anaerobiosis is to be avoided, while produce with a low respiration rate may be successfully packaged in material of low permeability. In some cases, a vacuum is initially used to remove all or a portion of the air from a package (Brown, 2003). The air is replaced with nitrogen or a predetermined mixture of gasses in order to create an “instant” modified atmosphere.

Produce stored in CA or MA environments should have a significant decrease in respiration rate, because as oxygen concentration is decreased respiration rate decreases (Kader and Saltveit, 2003). Significantly, the postharvest life of fresh vegetables is inversely related to their respiration rate (Kader and Saltveit, 2003). However, the most important factor in determining the respiration rate of fresh vegetables is temperature (Kader and Saltveit, 2003). There is typically a two to threefold decrease in respiration rate for every $10^{\circ} \mathrm{C}$ decrease in temperature (Kader and Saltveit, 2003).

MA packaging has many additional benefits besides reducing produce respiration rates. It maintains a high relative humidity around commodities, reducing water loss (Kader and Saltveit, 2003). It also improves sanitation by limiting the contamination of the commodity during handling. Surface abrasions due to contact between the commodity and shipping container are minimized. The contamination of produce from one unit to another is reduced. Exclusion of light is possible for photosensitive commodities (e.g. potatoes or Belgian endive). Films can contain fungicides, sprout 
inhibitors or other chemicals to improve storability. MA packages may be printed with logos, so brand identification is easier.

\section{Cauliflower and MAP:CA}

Commercially, MA packaging is used as the means to adjust the atmosphere surrounding cauliflower heads and florets. These MA packages reduce the oxygen level within the package to 2-3\% and increase the carbon dioxide level to 3-6\% (Kader and Saltveit, 2003). However, cauliflower, unlike broccoli, shows only slight beneficial effects from MA. In addition, cauliflower develops injury when stored below 2\% oxygen and/or above 5\% carbon dioxide (Kader and Saltveit, 2003). The injury is cryptic while the cauliflower is fresh, but when the cauliflower is cooked a grayish color appears (Hardenberg et al., 1993). If the oxygen level within the package drops to $<0.5 \%$, the cauliflower will develop off-odors and flavors due to fermentative metabolism (Forney and Jordan, 1999). The cauliflower will produce methanethiol, dimethyl disulfide, and dimethyl trisulfide (Forney and Jordan, 1999). Methanethiol is the volatile that produces the off-odor in many Brassica species (Forney and Jordan, 1999).

\section{Disinfectants}

\section{Ozone}

Ozone is a strong oxidizer that has been used as a disinfectant to treat water since the late 1890’s (Hendricks, 2006). However, the wash water must be thoroughly mixed and filtered to optimize ozone's efficacy. It has been shown to inactivate spores of Mucor piriformis and conidia of Botrytis cinerea in clean water solutions when at a 
concentration of $1.5 \mathrm{ppm}$ with 20 minutes contact time or $3.5 \mathrm{ppm}$ with 2 minutes contact time.

The downsides to ozone are that it is lethal to human at levels above $4 \mathrm{ppm}$ with sufficient exposure, it is very corrosive especially to substances with a carbon-carbon double bond (i.e., rubber, latex, ethylene, etc.) and its efficacy is highly reduced in solutions high in organic matter (Brown and Warfield, 1995). Ozone molecules are also very unstable at ambient temperatures and pressures and therefore they must be generated on site (Brown and Warfield, 1995).

\section{$\underline{\text { Sodium hypochlorite }}$}

Sodium hypochlorite is typically used in liquid form to treat wash water (Suslow, 1997). Wash water with higher concentrations of available chlorine requires less time to reduce microbial load (Brown and Warfield, 1995). Available chlorine is reduced when water temperature and/or the amount of organic matter in the wash water is increased. Combined chlorine does not effectively inactivate microbes, but available chlorine reacts quickly with microorganisms. The $\mathrm{pH}$ of the wash water should be maintained between 6.5 and 7.5 to prevent available chlorine from off gassing or converting to combined chlorine.

Sodium hypochlorite is an effective disinfectant at levels as low as $1 \mathrm{ppm}$ available chlorine, but is typically used in the produce industry at concentrations of 50-100 ppm available chlorine (Brown and Warfield, 1995). Since cauliflower is a low growing vegetable, it is recommended that cauliflower wash water contain 100 and 150 ppm available chlorine (Suslow, 1997). 


\section{Chlorine dioxide}

Chlorine dioxide can be used as both a gaseous and aqueous disinfectant. Aqueous $\mathrm{ClO}_{2}$ can be effectively used in wash water with a $\mathrm{pH}$ of 6 to 10 (Brown and Warfield, 1995). A chlorine dioxide wash at 20-200 ppm has been shown to be more effective than other common disinfectants at reducing the microbial load of E. coli O157: H7 from lettuce (Keskinen et al., 2009). Selective Micro Technologies (Winchester, OH), a manufacturer of chemical mixes to produce aqueous chlorine dioxide, recommends that produce wash water solutions contain $10 \mathrm{ppm} \mathrm{ClO}_{2}$ to extend product shelf-life. Park et al. (2008) showed that a 9 ppm concentration of chlorine dioxide in wash water significantly reduced the amount of bacteria in the wash water, but did not significantly reduce the amount of bacteria on the surface of potatoes washed in the water and attributed this to lenticels and other potato tuber surface features that may offer protection against sanitizers. Lee et al. (2004) demonstrated that $A$. acidoterrestris spore populations on apples can be reduced with a $40 \mathrm{ppm} \mathrm{ClO}_{2}$ wash. The Code of Federal Regulations, 21 CFR 178.1010 (2004), limits the amount of residual chlorine dioxide on produce at $3 \mathrm{ppm}$.

\section{Antibrowning Agents}

The combination of ascorbic acid and citric acid has been shown to prevent enzymatic browning on processed potatoes (Anonymous, 2001). Ascorbic acid can be used alone to prevent browning not only of potatoes, but also apples (Jongen, 2002). Ascorbic acid is an antioxidant, while citric acid is an acidifying agent (Brown, 2003). 
Calcium chloride has not been shown to reduce the amount of browning in fresh-cut produce, but has the ability to improve the firmness of fresh-cut cantaloupes and pears (Kader, 2002). The combination of a calcium source (calcium chloride or calcium carbonate) and ascorbic acid is used to prevent the browning and to maintain the quality of sliced apples (Lee, 1995).

Snow Fresh ${ }^{\circledR}$ is a browning-inhibitor produced by Monsanto (St. Louis, MO). It is a blend of sodium acid pyrophosphate with ascorbic acid, citric acid, and calcium chloride (Pilizota and Sapers, 2004). Maga (1995) showed that Snow Fresh was effective in maintaining the color of whole, peeled potatoes. Lee et al. (1995) demonstrated that apple slice washed in a 1\% solution of SnowFresh developed less browning over 21 days in storage at $3-5^{\circ} \mathrm{C}$.

\section{Summary}

Many factors contribute to extending cauliflower floret storability. Maintaining the cold chain is the most important strategy. When cauliflower is stored at $0^{\circ} \mathrm{C}$, its respiration rate slows considerably and the growth of spoilage organisms is also greatly reduced.

Modified atmosphere packing can extend the storability of properly chilled cauliflower florets by further slowing the respiration rate, delaying the onset of senescence.

Antibrowning agents are used to maintain produce postharvest quality by preventing discoloration due to enzymatic oxidation. Disinfectants can also reduce discoloration by 
reducing the numbers of spoilage organisms on product surfaces. The most commonly used disinfectant in the produce industry is hypochlorite, either sodium or calcium. 


\section{Materials and Methods}

\section{Microbiological Testing}

The objective of this test was to identify the type of microorganism that was responsible for browning of cauliflower florets. A floret with the characteristic browning was isolated and the brown section of the floret was added to $99 \mathrm{ml}$ of Butterfield's phosphate buffer. The diluted sample was then plated on 3M Microbiology (St. Paul, MN) Petrifilm aerobic count plates. Colonies from the petrifilm were then plated on aerobic plate count agar. Colonies were isolated and a bioMerieux API 20E kit was used to identify the microorganism.

\section{Ozone and Cauliflower Browning}

\section{$\underline{\text { Test } 1}$}

The objective of this test was to determine the efficacy of ozone in preventing the browning of cauliflower florets, whether of the curds or cut stems. Freshly floreted cauliflower was provided by Gold Coast Packing (Santa Maria, CA). Florets weighing a total of $9.1 \mathrm{~kg}$ were placed in a modified atmosphere (MA) shipping container (SLX International), (Fig. 1) which was placed in a cooler at $2.2^{\circ} \mathrm{C}$. An ozone generator (Del Industries, San Luis Obispo CA) was placed in a neighboring cooler, with $1 / 4$ ID Tygon $^{\circledR}$ tubing connecting the generator to the SLX box (Fig. 2). The generator produced ozone at a rate of $150 \mathrm{mg} / \mathrm{hr}$. The box was alternately flushed with ozone for 21 hours: The generator cycled 15 minutes on then 15 minutes off during this period, so the florets had 


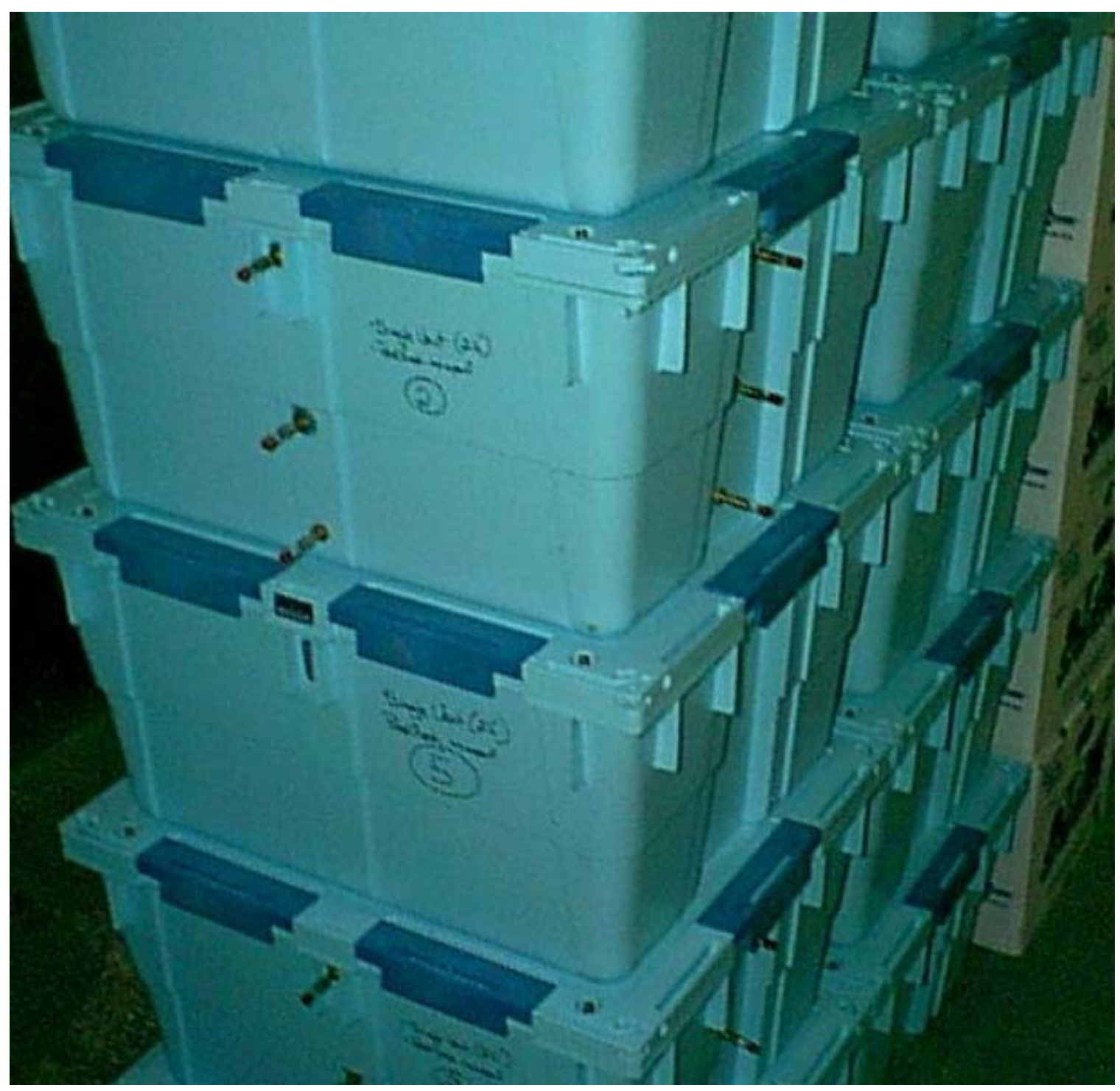

Fig. 1. Plastic modified-atmosphere shipping boxes (SLX International, San Luis Obispo, CA) used to store cauliflower during ozone treatment. Inlets and outlets for the ozonated air are visible. 


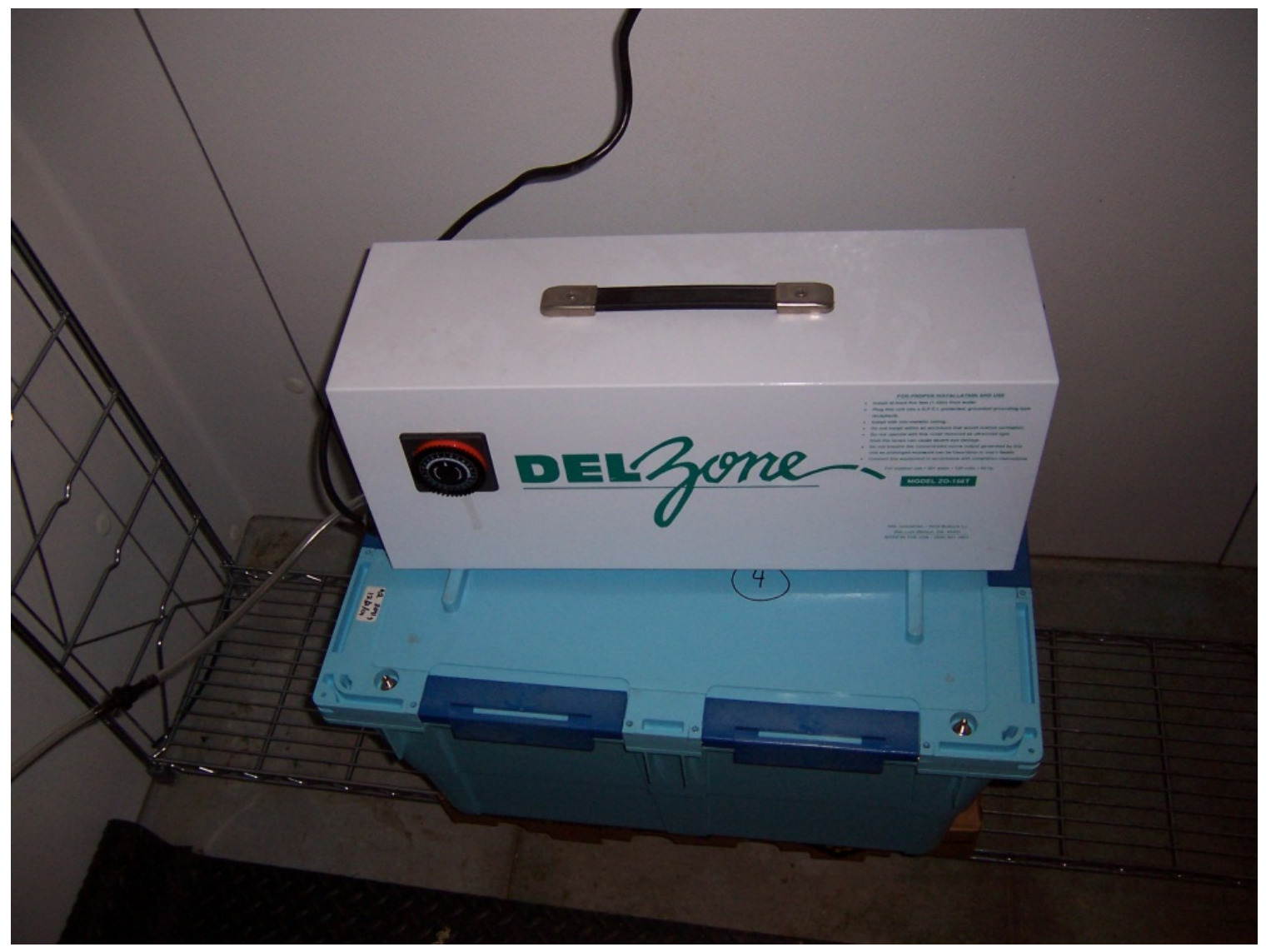

Fig. 2. Del Industries (San Luis Obispo, Ca) ozone generator model ZO-156T produces 150mg $\mathrm{O}_{3}$ /hour. 
10.5 hours of total exposure to ozone. After treatment, the florets were packed in 1.36 kg-sized microperforated cauliflower floret bags provided by Gold Coast Packing and stored at $7.2^{\circ} \mathrm{C}$ for the duration of the experiment (Fig. 3). Control (untreated) bags were also packed and stored at $7.2{ }^{\circ} \mathrm{C}$. During storage, the modified atmosphere (oxygen and carbon dioxide levels) within each package was measured. Fourteen days after ozonation, all packages were opened and the florets evaluated for appearance and odor.

\section{$\underline{\text { Test } 2}$}

This test repeated Test 1 except that two variables were altered. First, the florets were exposed to ozonated air for only 10 hours, i.e., the box was alternately flushed with ozone for 20 hours: the generator cycled 15 minutes on then 15 minutes off during this period. Second, the ozone generator was placed in a neighboring cooler, with $1 / 4$ ID Tygon $^{\circledR}$ tubing connecting the generator to a gallon jar of water that was kept at $2.2^{\circ} \mathrm{C}$. After the ozonated air was bubbled through the water it flowed into the SLX box.

\section{$\underline{\text { Test } 3}$}

This test repeated Test 2 except that the florets were exposed to ozonated air for only 1 hour, i.e., the box was alternately flushed with ozone for 2 hours: the generator cycled 15 minutes on then 15 minutes off during this period. 


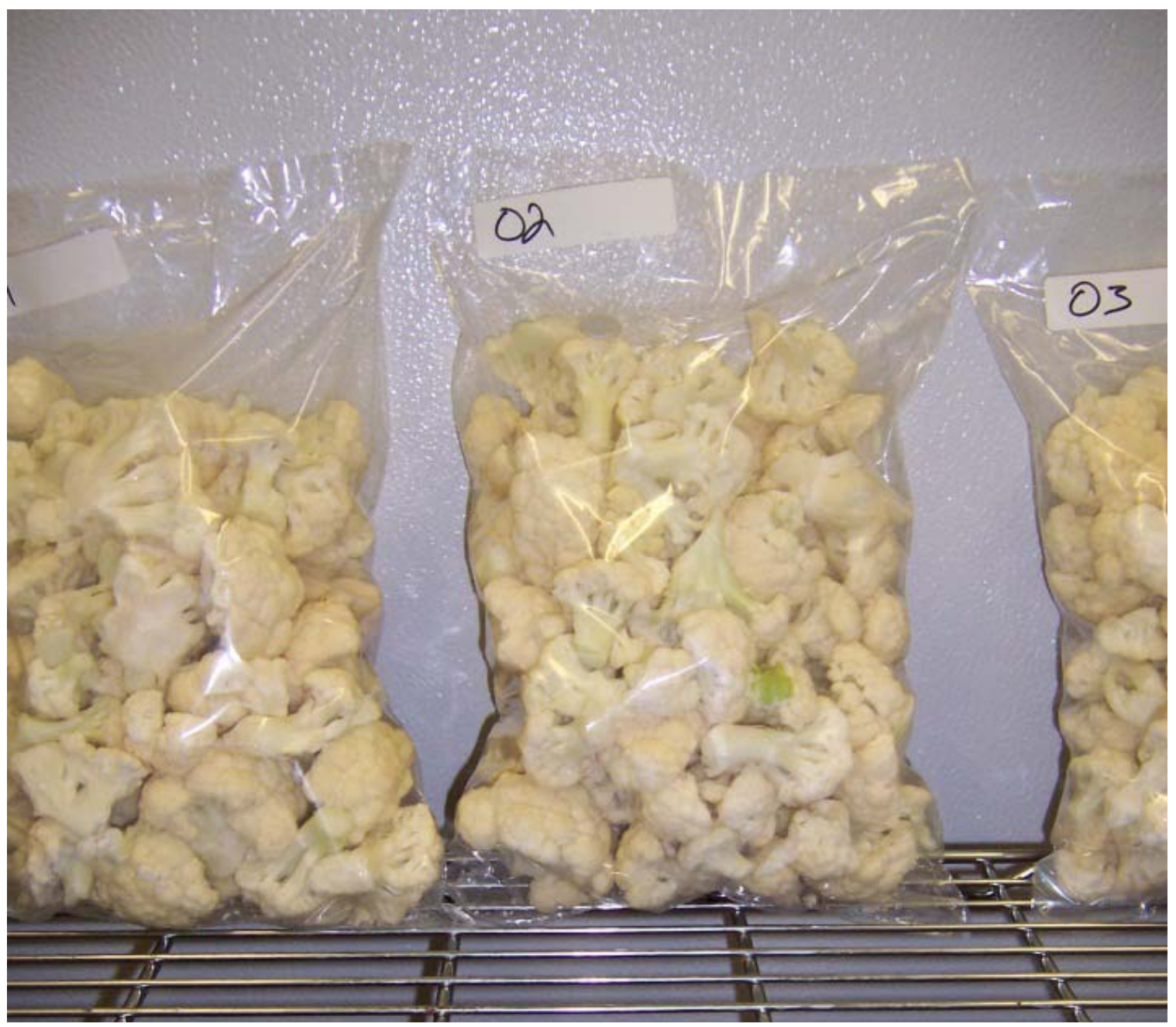

Fig. 3. Microperforated bag packed with $1.36 \mathrm{~kg}$ of cauliflower florets. Bags and cauliflower were supplied by Gold Coast Packing (Santa Maria, Ca). 


\section{Calcium Chloride and Cauliflower Browning}

\section{$\underline{\text { Test } 1}$}

The objective of this test was to determine the efficacy of calcium chloride in preventing or reducing the browning of cauliflower florets. Florets totaling $1.36 \mathrm{~kg}$ were treated by submersion in a tub that contained 24 liters of $1 \% \mathrm{CaCl}_{2}$. The solution was circulated around the florets using four Penguin pumps (Marineland, Atlanta GA), two with 1140 power heads (circulating 300 gallons per hour (gph)) and two with 550 power heads (circulating 145 gph). Treatments consisted of a 0, 30, 60 or 120 second submersion and fresh solution was used each time florets were submerged. The florets were removed from the treatment solution with a small netted scoop and placed into an Oxo (New York, NY) retail salad spinner. The florets were spun using ten pumps (about ten seconds of spin) and then the spin brake was applied slowly. Three replicates per treatment were packed in 1.36 kg-sized microperforated cauliflower floret bags. To simulate real-world conditions, the florets were stored at $2.2^{\circ} \mathrm{C}$ for 24 hours, after which the temperature was raised to $7.2^{\circ} \mathrm{C}$ for the remainder of the experiment. Control (untreated) bags were also packed and stored at $7.2^{\circ} \mathrm{C}$. During storage, the modified atmosphere within each package (oxygen and carbon dioxide levels) was monitored. Fourteen days after the florets were packed, the packages were opened and evaluated for appearance.

\section{$\underline{\text { Test } 2}$}

Test 2 repeated Test 1 except that the florets were exposed to the $1 \% \mathrm{CaCl}_{2}$ solution for only 0, 30 or 60 seconds and 4 replicates per treatment (including controls) were 
packed and stored. During storage, the modified atmosphere within each package (oxygen and carbon dioxide levels) was monitored. Fourteen days after the florets were packed, the packages were opened and evaluated for appearance.

$\underline{\text { Test } 3}$

Test 3 repeated Test 2 except that the florets were exposed to the $1 \% \mathrm{CaCl}_{2}$ solution for only 0, 10 or 30 seconds. During storage, the modified atmosphere within each package (oxygen and carbon dioxide levels) was monitored. Fifteen days after the florets were packed, the packages were opened and evaluated for appearance.

\section{Antibrowning Agents with Hypochlorite}

The objective of this test was to determine the efficacy of various calcium chloride:ascorbic acid:citric acid:hypochlorite combinations in preventing or reducing the browning of cauliflower florets. Unlike the previous experiments, cauliflower heads were provided by Gold Coast Packing and then floreted in the lab and washed or packaged immediately. This method of floreting the cauliflower heads just prior to being washed was used for the remainder of the experiments. Florets totaling $1.36 \mathrm{~kg}$ were treated by submersion in a tub that contained 24 liters of circulating treatment solution (Table 2) and fresh solution was used for each replicate of $1.36 \mathrm{~kg}$ of florets. Florets were immersed for 10 seconds, regardless of treatment solution, and 4 replicates per treatment (including controls) were packed in $1.36 \mathrm{~kg}$-sized microperforated cauliflower floret bags. As before, the florets were stored at $2.2^{\circ} \mathrm{C}$ for 24 hours, after which the 
Table 2. Calcium chloride, ascorbic acid, citric acid, hypochlorite combinations and concentrations used to treat cauliflower florets.

\begin{tabular}{|c|c|c|c|c|}
\hline $\begin{array}{c}\text { Treatment } \\
\text { Solution }\end{array}$ & $\mathrm{CaCl}_{2}$ & Ascorbate & Citrate & Hypochlorite \\
\hline 1 & $1 \%$ & $0 \mathrm{ppm}$ & $0 \mathrm{ppm}$ & \\
\hline 2 & $1 \%$ & 500 ppm & 250 ppm & \\
\hline 3 & $1 \%$ & 0 ppm & 500 ppm & \\
\hline 4 & $1 \%$ & 500 ppm & $500 \mathrm{ppm}$ & \\
\hline 5 & $1 \%$ & 0 ppm & 1000 ppm & \\
\hline 6 & $1 \%$ & 250 ppm & 1000 ppm & \\
\hline 7 & $1 \%$ & 500 ppm & 1000 ppm & \\
\hline 8 & $1 \%$ & & & 200 ppm \\
\hline 9 & $0 \%$ & & & 200 ppm \\
\hline $10^{\mathrm{z}}$ & $0 \%$ & $0 \mathrm{ppm}$ & 0 ppm & $0 \mathrm{ppm}$ \\
\hline
\end{tabular}

${ }_{\mathrm{z}}$ These florets were not washed before they were packed.

temperature was raised to $7.2^{\circ} \mathrm{C}$ for the remainder of the study. During storage, the modified atmosphere within each package (oxygen and carbon dioxide levels) was monitored. Fourteen days after the florets were packed, the packages were opened and evaluated for appearance. 


\section{Antibrowning Agents, then Hypochlorite}

$\underline{\text { Test } 1}$

The objective of this test was to determine the efficacy of an ascorbic acid:citric acid wash, followed by submersion in a hypochlorite solution, on the development and severity of subsequent browning of cauliflower florets. Florets were treated by submersion in a tub that contained 24 liters of circulating treatment solution and fresh solution was used for each replicate of $1.36 \mathrm{~kg}$ of florets. The florets were initially washed in an ascorbic acid:citric acid solution for 30 seconds after which they were immersed in a $6.5( \pm 0.05) \mathrm{pH}$ hypochlorite solution for 10 or 30 seconds (Table 3$)$. Six replicates per treatment (including controls) were packed in $1.36 \mathrm{~kg}$-sized microperforated cauliflower floret bags. As before, the florets were stored at $2.2^{\circ} \mathrm{C}$ for 24 hours, after which the temperature was raised to $7.2^{\circ} \mathrm{C}$ for the remainder of the experiment (22 days total). The cauliflower was assessed for browning and decay after 9, 15 and 22 days of storage. Florets were given two scores for curd browning: the first was for the percentage of florets that had some level of browning and the second was for the intensity of browning on the florets. The intensity score was on a scale of 1 to 9 with $1=$ little browning and $9=$ completely brown. The two scores, percentage and intensity, were multiplied to derive an overall curd browning score. This number was then divided by 900 (900 was the highest possible score: 100\% of florets with browning at a severity of $9=100 \mathrm{X} 9$ ), converting the number into a decimal. This procedure was repeated for the stem browning scores. Lastly, the curd- and stem-browning decimal scores were averaged to produce an overall browning score for each replicate. 
Table 3. Ascorbic and citric acid combinations, and hypochlorite concentrations, used in a two-step cauliflower wash sequence.

Treatment

Sequence

Ascorbate

Citrate

Hypochlorite

1

$0 \mathrm{ppm}$

$0 \mathrm{ppm}$

100 ppm, $10 \mathrm{sec}$

2

$0 \mathrm{ppm}$

0 ppm

100 ppm, 30 sec

3

250 ppm

500 ppm

100 ppm, 10 sec

4

250 ppm

500 ppm

100 ppm, 30 sec

5

250 ppm

500 ppm

0 ppm

$6^{\mathrm{z}}$

$0 \mathrm{ppm}$

0 ppm

0 ppm

${ }^{\mathrm{z}}$ These florets were not washed before they were packed.

$\underline{\text { Test } 2}$

The objective of this test was to determine the efficacy of an ascorbic acid:citric acid wash, followed by submersion in a hypochlorite solution, on the development and severity of subsequent browning of cauliflower florets. Florets totaling $1.36 \mathrm{~kg}$ were treated by submersion in a tub that contained 24 liters of circulating treatment solution and fresh solution was used with each $1.36 \mathrm{~kg}$ batch of florets. The florets were initially washed in an ascorbate:citric acid wash for 30 seconds followed by a $6.5( \pm 0.05) \mathrm{pH}$ hypochlorite solution for 10 or 30 seconds (Table 4). Three replicates per treatment (including controls) were packed in 1.36 kg-sized microperforated cauliflower floret 
Table 4. Hypochlorite concentration and ascorbate:citric acid combinations used in a two-step cauliflower wash sequence.

\section{Treatment}

$\begin{array}{ccccc}\text { Sequence } & \text { Hypochlorite } & \text { Ascorbate } & \text { Citrate } & \text { Storage }\left({ }^{\circ} \mathrm{C}\right) \\ 1^{\mathrm{z}} & 0 \mathrm{ppm} & 0 \mathrm{ppm} & 0 \mathrm{ppm} & 1.7 \\ 2^{\mathrm{z}} & 0 \mathrm{ppm} & 0 \mathrm{ppm} & 0 \mathrm{ppm} & 4.4 \\ 3^{\mathrm{z}} & 0 \mathrm{ppm} & 0 \mathrm{ppm} & 0 \mathrm{ppm} & 7.2 \\ 4 & 100 \mathrm{ppm}, 10 \mathrm{sec} & 250 \mathrm{ppm} & 500 \mathrm{ppm} & 1.7 \\ 5 & 100 \mathrm{ppm}, 10 \mathrm{sec} & 250 \mathrm{ppm} & 500 \mathrm{ppm} & 4.4 \\ 6 & 100 \mathrm{ppm}, 10 \mathrm{sec} & 250 \mathrm{ppm} & 500 \mathrm{ppm} & 7.2 \\ 7 & 100 \mathrm{ppm}, 30 \mathrm{sec} & 250 \mathrm{ppm} & 500 \mathrm{ppm} & 1.7 \\ 8 & 100 \mathrm{ppm}, 30 \mathrm{sec} & 250 \mathrm{ppm} & 500 \mathrm{ppm} & 4.4 \\ 9 & 100 \mathrm{ppm}, 30 \mathrm{sec} & 250 \mathrm{ppm} & 500 \mathrm{ppm} & 7.2\end{array}$

${ }^{\mathrm{z}}$ These florets were not washed before they were packed.

bags. The florets were stored at $1.7,4.4$ or $7.2^{\circ} \mathrm{C}$ for 14 days at which time the florets were inspected for curd yellowing, and stem and curd browning. Florets were given two scores for curd browning: the first was for the percentage of florets that had some level of browning and the second was for the intensity of browning on the florets. The intensity score was on a scale of 1 to 9 with $1=$ little browning and $9=$ completely brown. The two scores, percentage and intensity, were multiplied to derive an overall 
curd browning score. This number was then divided by 900 (900 was the highest possible score: $100 \%$ of florets with browning at a severity of $9=100 \mathrm{X} 9$ ), converting the number into a decimal. This procedure was repeated for the stem browning scores. Lastly, the curd- and stem-browning decimal scores were averaged to produce an overall browning score for each replicate.

\section{$\underline{\text { Test } 3}$}

The objective of this test was to determine the efficacy of experimental antibrowning solutions when compared to a commercial formulation, on the development and severity of cauliflower floret browning. Treatments consisted of 1) a control (no wash), 2) submersion in a solution of $250 \mathrm{ppm}$ ascorbic acid:500 ppm citric acid for $30 \mathrm{sec}$ followed by a 30 second hypochlorite wash, 3) submersion in a solution of $1 \%$ SnowFresh $^{\circledR}$ for 30 sec followed by submersion in 100 ppm sodium hypochlorite for 30 sec, and, 4) submersion in a solution of 100 ppm sodium hypochlorite for 30 sec followed by submersion in $1 \%$ SnowFresh ${ }^{\circledR}$ for $30 \mathrm{sec}$. Florets totaling $1.36 \mathrm{~kg}$ were batch treated in a tub that contained 24 liters of circulating treatment solution and fresh solution was used for each new batch. Five replicates per treatment (including controls) were packed in 1.36 kg-sized microperforated cauliflower floret bags. As before, the florets were stored at $2.2^{\circ} \mathrm{C}$ for 24 hours, after which the temperature was raised to $7.2^{\circ} \mathrm{C}$ for the remainder of the experiment. After 14 days of storage, the florets were inspected for curd yellowing, stem browning, and curd browning. Florets were given two scores for curd browning: the first was for the percentage of florets that had some level of browning and the second was for the intensity of browning on the florets. The intensity score was on a scale of 1 to 9 with 1 = little browning and $9=$ completely brown. The two scores, 
percentage and intensity, were multiplied to derive an overall curd browning score. This number was then divided by 900 (900 was the highest possible score: $100 \%$ of florets with browning at a severity of $9=100 \times$ 9), converting the number into a decimal. This procedure was repeated for the stem browning scores. Lastly, the curd- and stembrowning decimal scores were averaged to produce an overall browning score for each replicate.

\section{$\underline{\text { Test } 4}$}

The objective of this test was to determine the efficacy of chlorine dioxide, as a wash and as a gaseous treatment, on the development and severity of cauliflower floret browning. Treatments consisted of 1) a control (no wash), 2) submersion in a solution of $10 \mathrm{ppm}$ chlorine dioxide for $30 \mathrm{sec}$ (the solution was adjusted to $8.5 \mathrm{pH}( \pm 0.05)$ with $\mathrm{NaOH})$ followed by packaging with a chlorine-dioxide producing sheet $(20.3 \times 30.5 \mathrm{~cm})$, 3) unwashed florets packaged with a chlorine-dioxide producing sheet $(20.3 \times 30.5 \mathrm{~cm})$, 4) submersion in a solution of $10 \mathrm{ppm}$ chlorine dioxide for $30 \mathrm{sec}$ (the solution was adjusted to $6.5 \mathrm{pH}( \pm 0.05)$ with $\mathrm{HCl})$ followed by packaging, 5) submersion in a solution of 250 ppm ascorbic acid:500 ppm citric acid for 30 sec followed by submersion in 100 ppm sodium hypochlorite (adjusted to $6.5 \mathrm{pH}( \pm 0.05)$ with $\mathrm{HCl})$ for 30 sec after which the florets were packaged with a chlorine-dioxide producing sheet (20.3 x $30.5 \mathrm{~cm}), 6)$ submersion in a solution of $10 \mathrm{ppm}$ chlorine dioxide for $30 \mathrm{sec}$ (solution was adjusted to $8.5 \mathrm{pH}( \pm 0.05)$ with $\mathrm{NaOH})$ followed by packaging, and, 7) submersion in a solution of 250 ppm ascorbic acid:500 ppm citric acid for $30 \mathrm{sec}$ followed by submersion in 100 ppm sodium hypochlorite (adjusted to $6.5 \mathrm{pH}( \pm 0.05)$ with $\mathrm{HCl})$ for $30 \mathrm{sec}$, followed by 
packaging (Table 5). Florets totaling $1.36 \mathrm{~kg}$ were batch treated in a tub that contained 24 liters of circulating treatment solution and fresh solution was used for each new batch. Three replicates per treatment (including controls) were packaged in 1.36 kg-sized microperforated cauliflower floret bags. As before, the florets were stored at $2.2^{\circ} \mathrm{C}$ for 24 hours, after which the temperature was raised to $7.2^{\circ} \mathrm{C}$ for the remainder of the experiment. After 14 days of storage, the florets were inspected for curd yellowing, stem browning, and curd browning. Florets were given two scores for curd browning: the first was for the percentage of florets that had some level of browning and the second was for the intensity of browning on the florets. The intensity score was on a scale of 1 to 9 with $1=$ little browning and $9=$ completely brown. The two scores, percentage and intensity, were multiplied to derive an overall curd browning score. This number was then divided by 900 (900 was the highest possible score: 100\% of florets with browning at a severity of $9=100 \times$ 9), converting the number into a decimal. This procedure was repeated for the stem browning scores. Lastly, the curd- and stem-browning decimal scores were averaged to produce an overall browning score for each replicate.

$\underline{\text { Analysis }}$

Data was analyzed using SAS Learning Edition 2.0 (SAS Institute, Raleigh, NC). Significant differences were detected between treatments using Duncan’s Multiple Range Test. 
Table 5. Chlorine dioxide, hypochlorite and ascorbate:citric acid combinations used in a two-step cauliflower wash sequence.

Treatment

$\begin{array}{ccccc}\text { Sequence } & \text { Chlorine dioxide } & \text { Hypochlorite } & \text { Ascorbate } & \text { Citrate } \\ 1^{\mathrm{y}} & 0 \mathrm{ppm} & 0 \mathrm{ppm} & 0 \mathrm{ppm} & 0 \mathrm{ppm} \\ 2^{\mathrm{z}} & 10 \mathrm{ppm}(8.5 \mathrm{pH}) & 0 \mathrm{ppm} & 0 \mathrm{ppm} & 0 \mathrm{ppm} \\ 3^{\mathrm{z}} & 0 \mathrm{ppm} & 0 \mathrm{ppm} & 0 \mathrm{ppm} & 0 \mathrm{ppm} \\ 4 & 10 \mathrm{ppm}(6.5 \mathrm{pH}) & 0 \mathrm{ppm} & 0 \mathrm{ppm} & 0 \mathrm{ppm} \\ 5^{\mathrm{z}} & 0 \mathrm{ppm} & 100 \mathrm{ppm} & 250 \mathrm{ppm} & 500 \mathrm{ppm} \\ 6 & 10 \mathrm{ppm}(8.5 \mathrm{pH}) & 0 \mathrm{ppm} & 0 \mathrm{ppm} & 0 \mathrm{ppm} \\ 7 & 0 \mathrm{ppm} & 100 \mathrm{ppm} & 250 \mathrm{ppm} & 500 \mathrm{ppm}\end{array}$

${ }^{\mathrm{y}}$ These florets were not washed before they were packed.

${ }^{\mathrm{z}}$ These florets packed with a 20.3 x $30.5 \mathrm{~cm}$ chlorine-dioxide producing sheet. 


\section{Results}

\section{Microbiological Testing}

Preliminary results indicate that a Pseudomonas species was responsible, in great part, for the development of browning on cauliflower florets.

\section{Ozone and Cauliflower Browning}

\section{$\underline{\text { Test } 1}$}

For this test, florets were exposed to 10.5 total hours of ozone over a 21 hour period. The control cauliflower florets stored much better than the ozonated florets. After 14 days storage, the control florets had developed a little browning, some yellowing. The ozonated florets had dry stems, yellow florets, and the florets in some packages had an off-odor after two weeks storage at $7.2^{\circ} \mathrm{C}$. Overall the $\mathrm{O}_{2}$ and $\mathrm{CO}_{2}$ levels were acceptable. None of the bags contained an atmosphere that would cause the product to go anaerobic. Likewise, in all subsequent tests, bag atmospheres were tested and found to be aerobic so anaerobiosis was not a consideration in these studies.

\section{$\underline{\text { Test } 2}$}

For this test, florets were exposed to 10 total hours of ozone over a 20 hour period. As in the first test, the control florets stored better than the ozonated florets. Overall, the control florets developed some browning, some yellowing, and had an acceptable smell, while the ozonated florets were somewhat dry and had developed an orange discoloration during two weeks storage at $7.2^{\circ} \mathrm{C}$. 


\section{$\underline{\text { Test } 3}$}

For this test, florets were exposed to 1 total hour of ozone over a 2 hour period. Even with only 1 hour total exposure, the control florets stored better than the ozonated florets. Overall, the control florets had little browning, some yellowing, and had an acceptable smell, while the ozonated florets developed an orange discoloration during two weeks at 7. $2^{\circ} \mathrm{C}$.

\section{Calcium Chloride and Cauliflower Browning}

\section{$\underline{\text { Test } 1}$}

This test was conducted to determine the efficacy of a $1 \% \mathrm{CaCl}_{2}$ solution in preventing or reducing the browning of cauliflower florets. Florets were submerged for 0, 30, 60 or 120 seconds in the solution before storage for 14 days. The florets, for all treatments, were in excellent condition after 11 days of storage at $7.2^{\circ} \mathrm{C}$. By day 14 , the $\mathrm{CaCl}_{2}$-treated florets exhibited significant breakdown which manifested as a yellowish mush. The control florets also had more than normal breakdown by day 14 . The breakdown of the florets may have been due to the initial condition of the florets themselves as they had a strong cauliflower odor when they were originally picked up in Santa Maria. The florets were packed in an $18.2 \mathrm{~kg}$ poly-lined box and it was observed that there was $2.5 \mathrm{~cm}$ of standing water in the bag when it was initially opened.

\section{$\underline{\text { Test } 2}$}

This test was also conducted to determine the efficacy of a $1 \% \mathrm{CaCl}_{2}$ solution in preventing or reducing the browning of cauliflower florets. Florets were submerged for 
0,30 , or 60 seconds in the solution before storage for 14 days. The florets, for all treatments, looked similar after 14 days storage. However, there were some differences between the treatments (Table 6). The 30-second treatment ranked best for three of the four replicates, and next to best for the fourth. The 60 -second treatment ranked next to best for three of the four reps and best in the fourth. The treatment that was not washed (control) ranked last regardless of replication. The florets from each treatment developed browning on the cut area of the stems, and some browning on the curd (Fig. 4).

\section{$\underline{\text { Test } 3}$}

As with tests 1 and 2, this test was conducted to determine the efficacy of a $1 \% \mathrm{CaCl}_{2}$ solution in preventing or reducing the browning of cauliflower florets. For this test, however, florets were submerged for 0,10 , or 30 seconds in the solution before storage for 14 days. After storage, florets were scored for the percentage of florets that appeared edible. Browning was the only defect observed on florets from this experiment and the treatments were ranked from best to worst (Table 7). A 10- or 30-second dip resulted in the same percentage of edible florets, $87.5 \%$ and $86.25 \%$, respectively, at the end of the storage period. In contrast, florets that were not washed, only $77.5 \%$ of the florets were edible at the end of the storage period.

\section{Antibrowning Agents with Hypochlorite}

The objective of this test was to determine the efficacy of various calcium chloride:ascorbic acid:citic acid:hypochlorite combinations in preventing or reducing the 


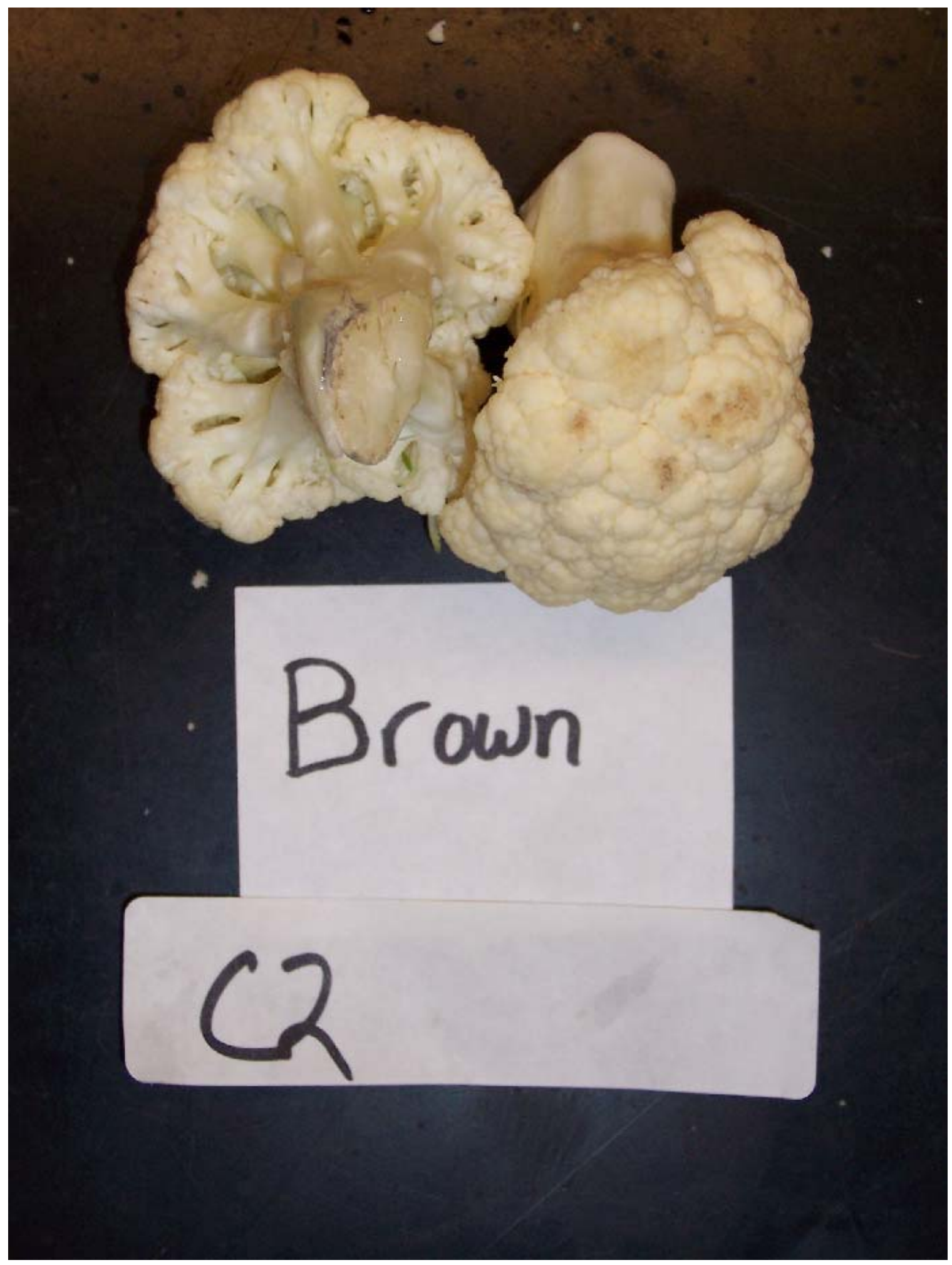

Fig. 4. Cauliflower florets that have developed stem (left) and curd (right) browning. 
Table 6. Rankings of overall quality, as determined by browning, for cauliflower florets treated with $\mathrm{CaCl}_{2}$ where $1=$ most effective and $3=$ least effective.

\begin{tabular}{lccccc}
\hline \hline Treatment & Rep 1 & Rep 2 & Rep 3 & Rep 4 & Avg. \\
\hline Control = No Wash & 3 & 3 & 3 & 3 & $3.00 \mathrm{~b}$ \\
30 sec $\mathrm{CaCl}_{2}$ Wash & 1 & 1 & 1 & 2 & $1.25 \mathrm{a}$ \\
60 sec $\mathrm{CaCl}_{2}$ wash & 2 & 2 & 2 & 1 & $1.75 \mathrm{a}$ \\
\hline
\end{tabular}

Table 7. Results of overall quality for cauliflower florets treated with $\mathrm{CaCl}_{2}$. Each package was scored for percentage of florets that were still edible at the end of the study.

\begin{tabular}{lccccc}
\hline \hline Treatment & Rep 1 & Rep 2 & Rep 3 & Rep 4 & Avg. \\
\hline Control = No Wash & 70 & 75 & 80 & 85 & $77.50 \mathrm{~b}$ \\
10 sec $\mathrm{CaCl}_{2}$ Wash & 80 & 90 & 90 & 90 & $87.50 \mathrm{a}$ \\
30 sec $\mathrm{CaCl}_{2}$ wash & 90 & 85 & 90 & 80 & $86.25 \mathrm{a}$ \\
\hline
\end{tabular}

browning of cauliflower florets. Overall, the florets from two treatments stored poorly: those that were treated with $1 \% \mathrm{CaCl}_{2}, 250$ ppm ascorbic acid plus 1000 ppm citric acid, and the control treatment (no wash) (Table 8). It appeared that when the amount of acid (ascorbate + citrate) exceeded 1000 ppm (Treatment 6, 7), cauliflower quality during storage was reduced. Likewise, the use of calcium chloride and sodium hypochlorite 
Table 8. Quality of cauliflower florets treated with various $\mathrm{CaCl}_{2}$ :ascorbic acid:citric acid:sodium hypochlorite combinations. Florets were evaluated after fourteen days storage.

\begin{tabular}{|c|c|c|c|c|c|}
\hline $\begin{array}{c}\text { Treatment } \\
\text { Solution }\end{array}$ & $\mathrm{CaCl}_{2}$ & Ascorbate & Citrate & Hypochlorite & Results \\
\hline 1 & $1 \%$ & $0 \mathrm{ppm}$ & $0 \mathrm{ppm}$ & & 1 \\
\hline 2 & $1 \%$ & 500 ppm & 250 ppm & & 1 \\
\hline 3 & $1 \%$ & 0 ppm & 500 ppm & & 1 \\
\hline 4 & $1 \%$ & 500 ppm & 500 ppm & & 1 \\
\hline 5 & $1 \%$ & 0 ppm & 1000 ppm & & 1 \\
\hline 6 & $1 \%$ & 250 ppm & 1000 ppm & & 3 \\
\hline 7 & $1 \%$ & 500 ppm & 1000 ppm & & 2 \\
\hline 8 & $1 \%$ & & & 200 ppm & 2 \\
\hline 9 & $0 \%$ & & & 200 ppm & 1 \\
\hline $10^{z}$ & $0 \%$ & $0 \mathrm{ppm}$ & 0 ppm & 0 ppm & 3 \\
\hline
\end{tabular}

$\mathrm{z}$ These florets were not washed before they were packed.

Result Key: 1=Unmarketable with slight browning, 2=Unmarketable with some browning, 3=Unmarketable with significant browning

reduced quality during storage. Quality was better, but still unmarketable, when sodium hypochlorite was used alone. 


\section{Antibrowning Agents, then Hypochlorite}

\section{$\underline{\text { Test } 1}$}

The objective of this test was to determine the efficacy of an ascorbic:citric acid wash, followed by submersion in a hypochlorite solution, on the development and severity of subsequent browning of cauliflower florets.

Nine Days Storage. The florets from the first replicate of each treatment were evaluated after nine days storage. Florets were ranked ( 1 = best; 6 = worst) for the amount of overall browning (Table 9). Florets treated with hypochlorite for 30 seconds had the least amount of browning indicating that the discoloration could be due to microbial growth, as the use of the antibrowning/antioxidant agents ascorbate and citrate, followed by a 30 second exposure to hypochlorite, had no additional effect. Overall, the biggest single factor with respect to the development of browning of the florets was the length of exposure to hypochlorite.

Fifteen and Twenty-two Days Storage. After 15 days storage, the florets from replicates 2 and 3 were evaluated for curd browning (Table 10), stem browning (Table 10), and percentage of yellowing. Lastly, the curd- and stem-browning decimal scores were averaged to produce an overall browning score for each replicate (Table 11). The percent yellowing score was determined by the percentage of florets that had noticeable curd yellowing. After the results were analyzed, significant differences were noticed between treatments (data not shown), but the negative attribute of yellowing was far less unappealing compared to the browning that developed. Therefore, further tests concentrated only on the curd and stem browning scores. 
Table 9. Rankings of overall quality for cauliflower florets stored for nine days. Values are for the first replicate of each treatment, only.

Antibrowning Treatment

\begin{tabular}{cccc}
\hline Acorbate & Citrate & Hypochlorite & $\begin{array}{c}\text { Visual } \\
\text { Ranking }^{z}\end{array}$ \\
\hline $0 \mathrm{ppm}$ & $0 \mathrm{ppm}$ & $100 \mathrm{ppm}, 30 \mathrm{sec}$ & 1.5 \\
$250 \mathrm{ppm}$ & $500 \mathrm{ppm}$ & $100 \mathrm{ppm}, 30 \mathrm{sec}$ & 1.5 \\
$250 \mathrm{ppm}$ & $500 \mathrm{ppm}$ & $0 \mathrm{ppm}$ & 3.0 \\
$0 \mathrm{ppm}$ & $0 \mathrm{ppm}$ & $100 \mathrm{ppm}, 10 \mathrm{sec}$ & 4.0 \\
$250 \mathrm{ppm}$ & $500 \mathrm{ppm}$ & $100 \mathrm{ppm}, 10 \mathrm{sec}$ & 5.0 \\
$0 \mathrm{ppm}$ & $0 \mathrm{ppm}$ & $0 \mathrm{ppm}$ & 6.0 \\
\hline
\end{tabular}

${ }^{\mathrm{z}}$ Rankings represent the average of the scoring of 2 evaluators, with 1 indicating the treatment with the least browning and 6 indicating the treatment with the most browning. 
Table 10. Curd and stem browning scores for cauliflower florets stored for 15 days. Results are for replicates two and three of each treatment.

Antibrowning Treatment

\begin{tabular}{|c|c|c|c|c|}
\hline Acorbate & Citrate & Hypochlorite & $\begin{array}{c}\text { Curd } \\
\text { Score }^{\mathrm{z}}\end{array}$ & $\begin{array}{c}\text { Stem } \\
\text { Score }^{\mathrm{y}}\end{array}$ \\
\hline 250 ppm & $500 \mathrm{ppm}$ & 100 ppm, 30 sec & $0.067 \mathrm{a}$ & $0.192 \mathrm{a}$ \\
\hline 0 ppm & $0 \mathrm{ppm}$ & 100 ppm, 30 sec & $0.111 \mathrm{ab}$ & $0.172 \mathrm{a}$ \\
\hline 250 ppm & $500 \mathrm{ppm}$ & 100 ppm, 10 sec & $0.114 \mathrm{ab}$ & $0.231 \mathrm{a}$ \\
\hline 0 ppm & 0 ppm & 100 ppm, 10 sec & $0.117 \mathrm{ab}$ & $0.100 \mathrm{a}$ \\
\hline 250 ppm & $500 \mathrm{ppm}$ & 0 ppm & $0.217 \mathrm{~b}$ & $0.122 \mathrm{a}$ \\
\hline 0 ppm & $0 \mathrm{ppm}$ & $0 \mathrm{ppm}$ & $0.475 \mathrm{c}$ & $0.581 \mathrm{~b}$ \\
\hline \multicolumn{5}{|c|}{$\begin{array}{l}\text { Curd browning score represents the amount of browning on the curd section of the } \\
\text { floret. The score was derived from the percentage of florets that had some browning } \\
\text { multiplied by the severity of the browning (scale of 1-9), that number was then divided } \\
\text { by } 900 \text { to get a final score. The higher the score, the more browning was present. } \\
\text { Stem browning score represents the amount of browning on the cut section of the stem } \\
\text { of the floret. The score was derived from the percentage of florets that had some } \\
\text { browning multiplied by the severity of the browning (scale of 1-9), that number was } \\
\text { then divided by } 900 \text { to get a final score. The higher the score, the more browning was } \\
\text { present. }\end{array}$} \\
\hline
\end{tabular}


Table 11. Overall score for cauliflower florets stored for 15 days. Results were for replicatess two and three of each treatment.

Antibrowning Treatment

\begin{tabular}{cccc}
\hline Acorbate & Citrate & Hypochlorite & $\begin{array}{c}\text { Overall } \\
\text { Score }^{\mathrm{z}}\end{array}$ \\
\hline $0 \mathrm{ppm}$ & $0 \mathrm{ppm}$ & $100 \mathrm{ppm}, 10 \mathrm{sec}$ & $0.108 \mathrm{a}$ \\
$250 \mathrm{ppm}$ & $500 \mathrm{ppm}$ & $100 \mathrm{ppm}, 30 \mathrm{sec}$ & $0.129 \mathrm{a}$ \\
$0 \mathrm{ppm}$ & $0 \mathrm{ppm}$ & $100 \mathrm{ppm}, 30 \mathrm{sec}$ & $0.142 \mathrm{a}$ \\
$250 \mathrm{ppm}$ & $500 \mathrm{ppm}$ & $0 \mathrm{ppm}$ & $0.169 \mathrm{a}$ \\
$250 \mathrm{ppm}$ & $500 \mathrm{ppm}$ & $100 \mathrm{ppm}, 10 \mathrm{sec}$ & $0.172 \mathrm{a}$ \\
$0 \mathrm{ppm}$ & $0 \mathrm{ppm}$ & $0 \mathrm{ppm}$ & $0.528 \mathrm{~b}$ \\
\hline
\end{tabular}

${ }^{\mathrm{z}}$ Overall score represents the average of the scores for curd and stem browning. Higher scores indicate a higher level of browning.

Cauliflower from replicates 4, 5, and 6 was evaluated for curd and stem browning after 22 days of storage. The procedure followed was the same as at 15 days. As with the florets stored for 15 days, after 22 days the florets from treatments that utilized a hypochlorite wash tended to have significantly less curd and stem (Table 12) and overall browning (Table 13). 
Table 12. Curd and stem browning scores of cauliflower florets stored for 22 days. Results are for replicates two and three of each treatment.

Antibrowning Treatment

\begin{tabular}{|c|c|c|c|c|}
\hline Acorbate & Citrate & Hypochlorite & $\begin{array}{c}\text { Curd } \\
\text { Score }^{\mathrm{z}} \\
\end{array}$ & $\begin{array}{c}\text { Stem } \\
\text { Score }^{\mathrm{y}}\end{array}$ \\
\hline 250 ppm & 500 ppm & 100 ppm, 30 sec & $0.241 \mathrm{a}$ & $0.229 \mathrm{a}$ \\
\hline 0 ppm & 0 ppm & 100 ppm, 30 sec & $0.289 \mathrm{a}$ & $0.439 \mathrm{~b}$ \\
\hline 250 ppm & 500 ppm & 100 ppm, 10 sec & $0.306 \mathrm{a}$ & $0.232 \mathrm{a}$ \\
\hline $0 \mathrm{ppm}$ & 0 ppm & 100 ppm, 10 sec & $0.324 \mathrm{a}$ & $0.264 \mathrm{a}$ \\
\hline 0 ppm & 0 ppm & $0 \mathrm{ppm}$ & $0.554 \mathrm{~b}$ & $0.648 \mathrm{c}$ \\
\hline 250 ppm & 500 ppm & $0 \mathrm{ppm}$ & $0.704 \mathrm{~b}$ & $0.426 \mathrm{~b}$ \\
\hline \multicolumn{5}{|c|}{$\begin{array}{l}\text { Curd browning score represents the amount of browning on the curd section of the } \\
\text { floret. The score was derived from the percentage of florets that had some browning } \\
\text { multiplied by the severity of the browning (scale of 1-9), that number was then divided } \\
\text { by } 900 \text { to get a final score. The higher the score, the more browning was present. } \\
\text { Stem browning score represents the amount of browning on the cut section of the stem } \\
\text { of the floret. The score was derived from the percentage of florets that had some } \\
\text { browning multiplied by the severity of the browning (scale of 1-9), that number was } \\
\text { then divided by } 900 \text { to get a final score. The higher the score, the more browning was } \\
\text { present. }\end{array}$} \\
\hline
\end{tabular}


Table 13. Overall discoloration scores for cauliflower florets stored for 22 days based on replicates four, five and six of each treatment.

Antibrowning Treatment

\begin{tabular}{cccc}
\hline Acorbate & Citrate & Hypochlorite & $\begin{array}{c}\text { Overall } \\
\text { Score }^{\mathrm{z}}\end{array}$ \\
$250 \mathrm{ppm}$ & $500 \mathrm{ppm}$ & $100 \mathrm{ppm}, 30 \mathrm{sec}$ & $0.235 \mathrm{a}$ \\
$250 \mathrm{ppm}$ & $500 \mathrm{ppm}$ & $100 \mathrm{ppm}, 10 \mathrm{sec}$ & $0.269 \mathrm{a}$ \\
$0 \mathrm{ppm}$ & $0 \mathrm{ppm}$ & $100 \mathrm{ppm}, 10 \mathrm{sec}$ & $0.294 \mathrm{a}$ \\
$0 \mathrm{ppm}$ & $0 \mathrm{ppm}$ & $100 \mathrm{ppm}, 30 \mathrm{sec}$ & $0.364 \mathrm{a}$ \\
$250 \mathrm{ppm}$ & $500 \mathrm{ppm}$ & $0 \mathrm{ppm}$ & $0.565 \mathrm{~b}$ \\
$0 \mathrm{ppm}$ & $0 \mathrm{ppm}$ & $0 \mathrm{ppm}$ & $0.601 \mathrm{~b}$ \\
& & & \\
\hline
\end{tabular}

${ }^{\mathrm{z}}$ Overall score represents the average of the scoring for curd and stem browning. The higher the score, the more browning was present.

\section{$\underline{\text { Test } 2}$}

The objective of this test was to determine the efficacy of an ascorbic acid:citric acid wash, followed by submersion in hypochlorite solution, on the development and severity of browning of cauliflower florets. Originally, the florets were to have been stored at 1.7, 4.4, and $7.2^{\circ} \mathrm{C}$. However, the cooler set at $4.4^{\circ} \mathrm{C}$ malfunctioned. The average temperature recorded on the cooler temperature log was $9.7^{\circ} \mathrm{C}$ and the data is reported based on this temperature. After fourteen days storage, the florets were evaluated for curd and stem browning (Table 14). 
Table 14. Curd and stem browning of cauliflower florets stored for 14 days. Results were for all replicates of each treatment.

\begin{tabular}{|c|c|c|c|}
\hline Treatment & $\begin{array}{l}\text { Temp } \\
\left({ }^{\circ} \mathrm{C}\right)\end{array}$ & $\begin{array}{l}\text { Curd }^{\mathrm{z}} \\
\text { Score }\end{array}$ & $\begin{array}{l}\text { Treatment } \\
\text { Average }\end{array}$ \\
\hline $\begin{array}{l}250 \text { ppm ascorbate:500 ppm citrate wash then } \\
30 \text { sec } 100 \text { ppm hypochlorite wash }\end{array}$ & $\begin{array}{l}1.7 \\
7.2 \\
9.7\end{array}$ & $\begin{array}{l}0.05 \\
0.23 \\
0.43\end{array}$ & $0.240 a^{x}$ \\
\hline $\begin{array}{l}250 \text { ppm ascorbate:500 ppm citrate wash then } \\
10 \text { sec } 100 \text { ppm hypochlorite wash }\end{array}$ & $\begin{array}{l}1.7 \\
7.2 \\
9.7\end{array}$ & $\begin{array}{l}0.06 \\
0.28 \\
0.42\end{array}$ & $0.249 \mathrm{a}$ \\
\hline Unwashed & $\begin{array}{l}1.7 \\
7.2 \\
9.7\end{array}$ & $\begin{array}{l}0.08 \\
0.33 \\
0.42\end{array}$ & $0.276 \mathrm{a}$ \\
\hline Treatment & $\begin{array}{l}\text { Temp } \\
\left({ }^{\circ} \mathrm{C}\right)\end{array}$ & $\begin{array}{l}\text { Stem }^{\mathrm{y}} \\
\text { Score }\end{array}$ & $\begin{array}{l}\text { Treatment } \\
\text { Average }\end{array}$ \\
\hline $\begin{array}{l}250 \text { ppm ascorbate:500 ppm citrate wash then } \\
30 \text { sec } 100 \text { ppm hypochlorite wash }\end{array}$ & $\begin{array}{l}1.7 \\
7.2 \\
9.7\end{array}$ & $\begin{array}{l}0.000 \\
0.217 \\
0.233\end{array}$ & $0.150 a^{x}$ \\
\hline $\begin{array}{l}250 \text { ppm ascorbate:500 ppm citrate wash then } \\
10 \text { sec } 100 \text { ppm hypochlorite wash }\end{array}$ & $\begin{array}{l}1.7 \\
7.2 \\
9.7\end{array}$ & $\begin{array}{l}0.000 \\
0.255 \\
0.341\end{array}$ & $0.198 \mathrm{ab}$ \\
\hline Unwashed & $\begin{array}{l}1.7 \\
7.2 \\
9.7\end{array}$ & $\begin{array}{l}0.000 \\
0.312 \\
0.362\end{array}$ & $0.225 \mathrm{~b}$ \\
\hline \multicolumn{4}{|c|}{$\begin{array}{l}\text { Curd browning score represents the amount of browning on the curd section of the } \\
\text { floret. The score was derived from the percentage of florets that had some browning } \\
\text { multiplied by the severity of the browning (scale of 1-9), that number was then divided } \\
\text { by } 900 \text { to get a final score. The higher the score, the more browning was present. } \\
\text { Stem browning score represents the amount of browning on the cut section of the stem } \\
\text { of the floret. The score was derived from the percentage of florets that had some } \\
\text { browning multiplied by the severity of the browning (scale of 1-9), that number was } \\
\text { then divided by } 900 \text { to get a final score. The higher the score, the more browning was } \\
\text { present. } \\
\text { Means within a column with the same letter are not significantly different at the } 95 \% \\
\text { confidence level according to Duncan's Multiple Range Test. }\end{array}$} \\
\hline
\end{tabular}


As would be expected, florets stored at lower temperatures developed less discoloration during storage (Table 14, 15). When looking at the overall effect of each treatment on floret browning, the unwashed florets had more browning than the florets washed with 250:500 ppm ascorbic:citric acid followed by a 30 second hypochlorite wash (Table 15). However, wash treatment had no effect on curd browning, per se (Table 14). In contrast, the florets washed with 250:500 ppm ascorbic:citric acid followed by a 30 second hypochlorite wash developed less stem browning than the unwashed florets (Table 14).

\section{$\underline{\text { Test } 3}$}

The objective of this test was to determine the efficacy of experimental antibrowning solutions when compared to a commercial formulation, on the development and severity of cauliflower floret browning. After fourteen days storage, the florets were evaluated for curd and stem browning (Table 16). The browning scores (stem and curd) were averaged to create an overall browning score (Table 17).

The florets treated with a final wash in hypochlorite or $250 \mathrm{ppm}$ ascorbate:500 ppm citrate developed less overall browning than the unwashed control florets (Table 17). When looking at the effect of the treatments on stem browning, there was a higher rate of browning of unwashed florets than the florets from all other treatments (Table 16). However, there were no differences in curd browning as affected by washing treatment. 
Table 15. Overall quality of cauliflower florets stored for 14 days. Results were for all replicates of each treatment and were based on both curd and stem browning scores.

\begin{tabular}{|c|c|c|c|}
\hline Treatment & $\begin{array}{l}\text { Temp } \\
\left({ }^{\circ} \mathrm{C}\right)\end{array}$ & $\begin{array}{l}\text { Average }^{\mathrm{z}} \\
\text { Score }\end{array}$ & $\begin{array}{l}\text { Treatment } \\
\text { Average }\end{array}$ \\
\hline 250 ppm ascorbate:500 ppm citrate wash then & 1.7 & 0.026 & $0.195 \mathrm{a}^{\mathrm{y}}$ \\
\hline \multirow[t]{2}{*}{30 sec 100 ppm hypochlorite wash } & 7.2 & 0.225 & \\
\hline & 9.7 & 0.334 & \\
\hline 250 ppm ascorbate:500 ppm citrate wash then & 1.7 & 0.028 & $0.224 \mathrm{ab}$ \\
\hline \multirow[t]{2}{*}{10 sec 100 ppm hypochlorite wash } & 7.2 & 0.265 & \\
\hline & 9.7 & 0.379 & \\
\hline \multirow[t]{3}{*}{ Unwashed } & 1.7 & 0.039 & $0.251 \mathrm{~b}$ \\
\hline & 7.2 & 0.320 & \\
\hline & 9.7 & 0.392 & \\
\hline \multicolumn{4}{|c|}{$\begin{array}{l}\text { Z Overall score represents the average of the scoring for curd and stem browning. The } \\
\text { higher the score, the more browning was present. }\end{array}$} \\
\hline \multicolumn{4}{|c|}{$\begin{array}{l}\text { y Means within a column with the same letter are not significantly different at the 95\% } \\
\text { confidence level according to Duncan’s Multiple Range Test. }\end{array}$} \\
\hline
\end{tabular}


Table 17. Rankings of overall quality for cauliflower florets stored for 14 days. Results were for all replicates of each treatment.

\begin{tabular}{|c|c|}
\hline Treatment & $\begin{array}{c}\text { Overall }^{\mathrm{z}} \\
\text { Score } \\
\end{array}$ \\
\hline 250/500 ppm ascorbate:citrate, then 100 ppm hypochlorite & $0.03 \mathrm{a}^{\mathrm{y}}$ \\
\hline 1\% SnowFresh wash, then 100 ppm hypochlorite & $0.04 \mathrm{a}$ \\
\hline 100 ppm hypochlorite, then $1 \%$ SnowFresh & $0.08 \mathrm{ab}$ \\
\hline No wash & $0.10 \mathrm{~b}$ \\
\hline \multicolumn{2}{|c|}{$\begin{array}{l}\text { Overall score represents the average of the scoring for curd and stem browning. The } \\
\text { higher the score, the more browning was present. }\end{array}$} \\
\hline \multicolumn{2}{|c|}{$\begin{array}{l}\text { Means within a column with the same letter are not significantly different at the } 95 \% \\
\text { confidence level according to Duncan's Multiple Range Test. }\end{array}$} \\
\hline
\end{tabular}

\section{$\underline{\text { Test } 4}$}

The objective of this test was to determine the efficacy of chlorine dioxide, as a wash and as a gaseous treatment, on the development and severity of cauliflower floret browning. After fourteen days of storage, the florets were evaluated for curd and stem browning (Table 18). The browning scores (stem and curd) were averaged to create an overall browning score (Table 19). The florets washed for 30 seconds in 10 ppm $\mathrm{ClO}_{2}$ solution adjusted to a $\mathrm{pH}$ of 8.5 and the florets washed for 30 seconds in $250 \mathrm{ppm}$ ascorbic acid/500ppm citric acid solution followed by a 30 second wash in 100 ppm hypochlorite solution had less overall browning than the unwashed florets, the florets

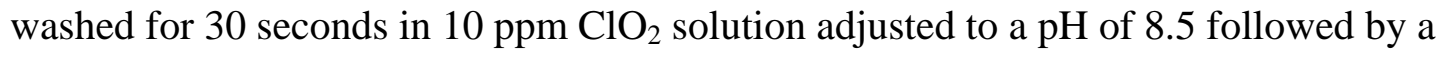
chlorine dioxide producing sheet placed in the bag, and the florets washed for 30 seconds in a $10 \mathrm{ppm} \mathrm{ClO}_{2}$ solution adjusted to a pH of 6.5 (Table 19). 
Table 19. Overall quality of cauliflower florets stored for 14 days. Results were for all replicates of each treatment.

Treatment

Average $^{\mathrm{z}}$

Score

30 sec 250 ppm ascorbic acid/500ppm citric acid,

$0.147 \mathrm{a}^{\mathrm{y}}$ then 30 sec 100 ppm hypochlorite

30 sec 10 ppm $\mathrm{ClO}_{2}$ wash@8.5 pH

$0.161 \mathrm{a}$

30 sec 250 ppm ascorbic acid/500ppm citric acid,

$0.221 \mathrm{ab}$ then 30 sec 100 ppm hypochlorite, then packed with $\mathrm{ClO}_{2}$-releasing sheet

No wash, packed with $\mathrm{ClO}_{2}$-releasing sheet

$0.262 \mathrm{ab}$

30 sec 10 ppm $\mathrm{ClO}_{2}$ wash@6.5 pH

$0.310 \mathrm{~b}$

Unwashed

$0.341 \mathrm{~b}$

30 sec 10 ppm $\mathrm{ClO}_{2}$ wash @ 8.5 pH,

$0.342 \mathrm{~b}$ then packed with $\mathrm{ClO}_{2}$-releasing sheet

${ }^{\mathrm{z}}$ Overall score represents the average of the scoring for curd and stem browning. The higher the score, the more browning was present.

${ }^{y}$ Means within a column with the same letter are not significantly different at the $95 \%$ confidence level according to Duncan’s Multiple Range Test. 


\section{Discussion}

\section{Ozone and Cauliflower Browning}

With the ozone experiments, browning of the florets was to be controlled with gaseous ozone. The ozonated florets did not store well. Ozone beaks down carboncarbon double bonds. The molecular structure of a cell wall consists of carbon-carbon double bonds. The prolonged exposure to ozone may have weakened the plant tissue enough to cause visible injury to the florets. Once the tissue had been weakened the florets were more susceptible to spoilage organisms. The concentration of ozone being discharged from the ozone generator could not be adjusted. If a generator became available that could adjust the concentration of ozone, it would be worth testing.

\section{Calcium Chloride and Cauliflower Browning}

The original container of florets that was picked up at Gold Coast Packing contained standing water in the bottom of the case. This may have caused the product to go anaerobic, resulting in mercaptan production, as a strong off-odor was present. Since the product was compromised the experiment was repeated. In the second experiment, the cauliflower from the treatment with the shorter dwell time (30 seconds) and one percent $\mathrm{CaCl}_{2}$ solution appeared to store better than the florets from the treatments with longer dwell times (60 and 120 seconds). The longer dwell time may have resulted in damaged plant tissues. The next experiment utilized shorter dwell times and the product treated for 10 or 30 seconds appeared to store slightly better. 


\section{Antibrowning Agents with Hypochlorite}

The next series of tests utilized various calcium chloride:ascorbic acid:citric acid:hypochlorite combinations. The florets that were treated with lower levels of ascorbic and citric acid appeared to store better than the control florets. As before, longer dwell time may have resulted in damaged plant tissues.

\section{Antibrowning Agents, then Hypochlorite}

These experiments were conducted to determine if a secondary wash in a sodium hypochlorite solution would prevent browning and help achieve a 21 day shelf life for cauliflower florets at $45^{\circ} \mathrm{F}$. Hypochlorite is one of the most effective and inexpensive sanitizing agents available (Brown and Warfield, 1995).

The florets, from treatments that utilized chlorine, stored better than the control florets. This indicates that the browning may be due to microbial growth and not enzymatic browning. Microbial tests indicated that cauliflower browning was due, at least in part, to the action of Pseudomonas bacteria.

In addition to hypochlorite, chlorine dioxide was also evaluated to determine it efficacy with cauliflower florets. Florets washed with chlorine dioxide at $8.5 \mathrm{pH}$ and florets washed with ascorbic:citric acid wash followed by hypochlorite developed less overall browning that control florets. Also, the florets washed with ascorbic/citric acid wash followed by hypochlorite developed less stem browning that the control florets.

The consistent good results with the ascorbic and citric acid wash followed by a hypochlorite wash indicates that the browning may be due to both enzymatic and microbial factors. When used practically, hypochlorite has the ability to reduce, but not 
eliminate, the microbial load on the surface of the florets. The remaining microorganisms can lead to spoilage, which may lead to enzymatic browning. The complimentary aspect of the ascorbic and citric acid (enzymatic browning inhibitor) wash followed by the hypochlorite (microbial browning inhibitor) wash may be why it has consistently minimized the amount of browning on the cauliflower florets. 


\section{Conclusions}

None of the treatments used throughout this research prevented cauliflower florets from developing brown spots during storage at $7.2^{\circ} \mathrm{C}$. The combination of a $250 \mathrm{ppm}$ ascorbic acid and 500ppm citric acid wash followed by a 100 ppm hypochlorite wash consistently reduced the amount of browning present on the florets, but did not reduce those levels enough for it to be considered a commercially viable method. Preliminary microbial work indicated an association between Pseudomonas species and cauliflower browning. Further studies should explore the synergistic effects of combining enzymatic browning inhibitor treatments with microbial browning inhibitor treatments. 


\section{References}

Anonymous. 2011. Floret. In: Merriam-Webster Online Dictionary. Merriam-Webster, Inc., Springfield, MA. Retrieved February 28, 2011, from http://www.merriamwebster.com/dictionary/floret?show=0\&t=1299014085.

Anonymous. 2001. Prevent enzymatic browning in peeled potatoes, other produce: An emerging food R\&D report. From Food Technology Intelligence, Inc., Midland Park, NJ. Retrieved from: http://www.entrepreneur.com/tradejournals/article/72806245.html.

Brown, J.W. 2003. California Vegetable Production Lab Supplement. El Corral Publications, San Luis Obispo, CA.

Brown, J.W. and D.L. Warfield. 1995. Readings in postharvest technology. El Corral Publications, San Luis Obispo, CA.

Canadian Food Inspection Agency. 2011. Cauliflower. Nepean, Ontario Canada.: CFIA. Available from: http://www.inspection.gc.ca/english/fssa/frefra/vegman/caucho/cauchoe.shtml

Cantwell, M. and T.V. Suslow. 2009. Cauliflower: Recommendations for maintaining postharvest quality. Postharvest Technology Research Information Center, Department of Plant Sciences, UC Davis, Davis, CA Retrieved Mar 1, 2011, from http://postharvest.ucdavis.edu/Produce/ProduceFacts/Veg/cauliflor.shtml.

FDA (Food and Drug Administration), CFR (Code of Federal Regulations) 21. 2004. Part 178.1010. Office of the Federal Register, National Archives and Records Administration, U.S. Government Printing Office, Washington, DC.

Forney, C.F. and M.A. Jordan. 1999. Anaerobic production of methanethiol and other compounds by Brassica vegetables. HortScience 34(4):696-699.

Hardenburg R.E., A.E. Watada and C.Y. Wang. 1993. The commercial storage of fruits, vegetables, and florist and nursery stocks. USDA Publication 66, US Government Printing Office, Washington, D.C.

Hendricks, D.W. 2006. Water treatment unit processes physical and chemical. CRC Press, Taylor Francis Group, LLC., Boca Raton, FL.

Jongen, W.M. 2002. Fruit and vegetable processing - Improving quality. Woodhead Publishing, Sawston, Cambridge, UK.

Kader, A.A. 2002. Postharvest technology of horticultural crops. Publ. 3311, University of California, Agriculture and Natural Resources, Oakland, CA. 
Kader, A.A. and M.E. Saltveit. 2003. Respiration and gas exchange. In: Postharvest Physiology and Pathology of Vegetables, p. 7-32. CRC Press, Taylor Francis Group, LLC., Boca Raton, FL.

Kader, A.A. and M.E. Saltveit. 2003. Atmosphere modification. In: Postharvest Physiology and Pathology of Vegetables, p. 250-270. CRC Press, Taylor Francis Group, LLC., Boca Raton, FL.

Keskinen, L.A., A. Burke and B.A. Annous. 2009. Efficacy of chlorine, acidic electrolyzed water and aqueous chlorine dioxide solutions to decontaminate Escherichia coli O157:H7 from lettuce leaves. International Journal of Food Microbiology 132:134-140.

Lee, C.Y. and N.L. Smith. 1995. Minimal processing of New York apples. New York's Food and Life Sciences Bulletin Number 145. Cornell University, Department of Food Science and Technology, Geneva, NY.

Lee, S.Y., P.M. Gray, R.H. Dougherty and D.H. Kang. 2004. The use of chlorine dioxide to control Alicyclobacillus acidoterrestris spores in aqueous suspension and on apples. International Journal of Food Microbiology 92:121-127.

Maga, J.A. 1995. Influence of dips, modified atmospheric packaging, and storage time on the enzymatic discoloration of processed raw potatoes. Developments in Food Science 37(1):491-495.

Mitchell, F.G., R. Guillou and R.A. Parsons. 1972. Commercial cooling of fruits and vegetables, Manual 43. California Agricultural Experiment Station Davis, CA.

National Agricultural Library. 2011. Raw Cauliflower. USDA, ARS, National Food Laboratory,. Washington, D.C. Retrieved from: http://www.nal.usda.gov/fnic/foodcomp/search/.

Park, E.J., P.M. Gray, S.W. Oh, J. Kronenberg and D.H. Kang. 2008. Efficacy of FIT produce wash and chlorine dioxide on pathogen control in fresh potatoes. Journal of Food Science 73(6):M273-M282.

Pilizota, V. and G.M. Sapers. 2004. Novel browning inhibitor formulation for fresh-cut apples. Journal of Food Science 69(4):SNQ140-SNQ143.

Ratti, C., H.R. Rabie and G.S.V. Raghavan. 1998. Modelling modified atmosphere storage of fresh cauliflower using diffusion channels. J. Agr. Eng. Res. 69:343-350.

Suslow, T. 1997. Postharvest chlorination: Basic properties and key points for effective disinfection. Publ. 8003, University of California, Agriculture and Natural Resources, Oakland, CA. 